\title{
MAPPING LEADING LOCAL CULTURE OF CIREBON TOURISM SECTOR USING GEOGRAPHIC INFORMATION SYSTEM (GIS)
}

\author{
Chairun Nas ${ }^{1}$, Wanda Ilham ${ }^{2}$ \\ ${ }^{1,2}$ Fakultas Teknologi \& Informasi, Universitas Catur Insan Cedekia \\ Jl. Kesambi No.202, Cirebon, Jawa Barat
}

\begin{tabular}{l} 
Article Info \\
\hline Article history: \\
Received 04 November, 2020 \\
Revised 06 June, 2021 \\
Accepted 06 June, 2021 \\
\hline
\end{tabular}

\section{Keywords:}

Tourism

Culture

Mapping

Geographical

Information

Systems

\begin{abstract}
The tourism sector is able to increase regional income, one of them is local cultural tourism. Cirebon as a cultural heritage city, it makes cultural tourism as leading regional tourism. Cirebon government always promote the leading cultural tourism of Cirebon city to tourists. However, the limited presentation of information to tourists has made some sectors of local cultural tourism untouched by tourists. The purpose of this research is to map the leading cultural tourism objects to be implemented into a system that can provide information of location and description for cultural tourism objects. In this research, the data was used the map of Cirebon city and 15 types of research object data in the tourism sector. They were processed and implemented into a Geographical Information System (GIS) and will be able to become a medium for Cirebon government to promote its leading cultural tourism.
\end{abstract}

This is an open access article under the CC BY-SA license.

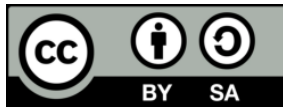

\section{Corresponding Author:}

Chairun Nas

Fakultass Teknologi \& Informasi, Universitas Catur Insan Cedekia

J1. Kesambi No.202, Cirebon, Jawa Barat

Email: chairun.nas@cic.ac.id

(C) Chairun Nas and Wanda Ilham 2021

\section{Introduction}

Indonesia is a big country consists of 1340 tribes and 300 ethnics. From this diversity, it has spesific characteristic culture. Culture is the whole complex of knowledge, beliefs, arts, morals, laws, norms and all abilities and habits of the society [1]. Culture can be seen from local wisdom, art, life habits and others. So, from this local culture can be an attraction for the tourism sector for introducing regional culture. The tourism sector can be a resource to carry out efforts to maintain or preserve various old culture [2]. It means the tourism can maintain the preservation of regional culture to introduce the spesific characteristic culture. The tourism can also increase regional income, and can create new jobs for local communities. Therefore, the local government carries out many promotions to introduce local cultural tourism aggressively.

As a city full of cultural heritage, Cirebon has become an attraction for tourists on cultural tours such as arts, dances and regional specialties. The efforts of the Cirebon government in improving the tourism sector to attract tourists continually. One of them is promoting the leading cultural tourism of the region. However, due to the lack of information of several sectors of cultural tourism are still untouched by tourists. To solve this problem, it is necessary to map the local cultural tourism objects. It will be implemented into a system that provides information of location and detailed description of these local cultural tourism objects using the Geographic Information System (GIS). 
In previous research, GIS has been used for mapping the Culinary, Arts and Culture of Balikpapan city. In this study, several research objects were used and the mapping was carried out using the MapInfo application. The mapping results will be implemented into the Andorid application. The result of this study to know the location of culinary, art and cultural object by using GIS Android-based [3]. Beside that research, there is another research, it's about mapping of traditional markets in Denpasar. This research also been implemented into GIS to map Denpasar area and 4 traditional markets and to determine the coordinate positions. The result of this research is GIS which can provide information to tourists about the location and description of traditional markets in Denpasar [4].

Thus, from the previous researches discussed, Android-based GIS is suitable for mapping leading local culture in the tourism sector in Cirebon as a promotional media for tourists.

\section{Research Method}

\subsection{Literature Review}

2.1.1 Local Cultural Tourism

Cultural tourism is culture as main attraction of tourism to introduce the culture and local wisdom for tourists [5]. The existence of cultural tourism, Cirebon government able to promote the cultural heritage in Cirebon. The tourism sector is one of the income-supporting sectors to maximize the potential existence at local area [2]. In this research, cultural tourism is divided into several classifications, such as:

a. Traditional Arts Classification

Traditional art tourism is a tour to introduce the traditional arts in an area that given the messages about knowledge, ideas, beliefs and norm values from the society [6]. The examples of traditional art tourism are music, dance, puppets, carvings, performances and others.

b. Cultural Heritage Classification

Cultural heritage tourism is a tour to introduce the historical relics in an area like buildings, structures, sites and cultural heritage that be preserved because they have important values for history, religion, education, science and culture [7].

c. Regional Culinary Specific Cuisine Classification.

Every region has its own special or specific food that be attracts for tourists visiting an area. Culinary tourism can also support the development of other tourism, because in every tourism object there are the vendors who sell their own specific food..

2.2 Mapping

A map can be explained as description of condition of the surface of a certain area which is indicated by symbols, signs and informations on a certain scale [8]. It can be interpreted that mapping is a process carried out to describe the surface of an area by using symbols, signs and information. In this research, it is necessary to map the locations of research objects to implement into a Geographical Information System to produce digital map. The following geographical location of Cirebon city on picture 1 below :

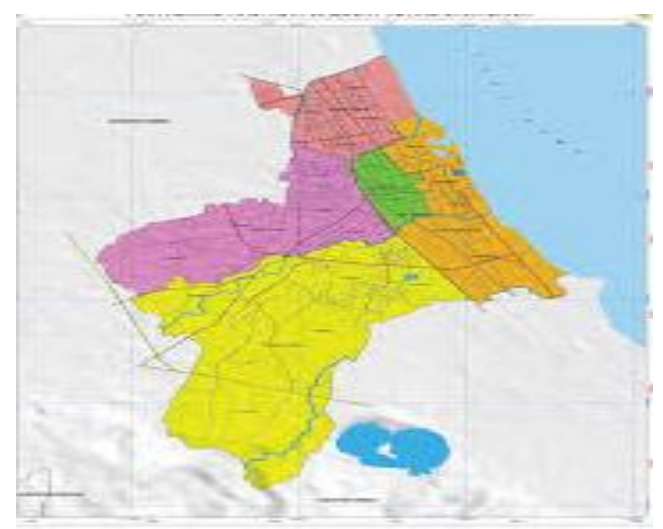

Figure 1. Peta Kota Cirebon

Cirebon City is one of the cities in West Java province which is connecting city from Jakarta to Central Java or East Java. Geographically, Cirebon is located at 108.33 o and 6.41o south latitude on the North coast of Java Island, the eastern part of West Java. Cirebon city is located at an altitude of 5 meters above sea level, so Cirebon is categorized as a lowland. Cirebon city area is $37.35 \mathrm{~km} 2$ or $3,735.8$ hectares.

2.3 Geographical Information Systems (GIS) 
GIS is an information system that is used to input, store, process, analyze and generate geospatial or referenced data to support decision making [9]. By using GIS, a mapping of an area or location can be digitized. Another benefit of GIS is makes the easy for decision maker to determine the goal, especially those related to spatial aspects [10]. In GIS, there is a data model as follows [9]:

a. Spatial Data.

Data related to location, position is geometric and relates to geographic elements. The spatial data model consists of Raster Data and Vector Data.

b. Non Spatial Data

Data related to the description of geographic elements such as names, addresses and others.

In GIS, there are subsystems that build it. The subsystems in the geographic information system are as follow [11]:

a. Input data: to collect spatial and attribute data from various data sources.

b. Output Data: to serves the display databases in both softcopy and hardcopy such as tables, graphics and maps.

c. Data Management: to organize both spatial data and attribute data into a database.

d. Data Manipulation \& Analysis: functions to manipulate and model data to produce the expected information.

\subsection{Methodology in GIS development.}

The methodology in GIS development uses the System Development Life Circle (SDLC) method where eachstage in system development will be carried out in descending order. The form of the SDLC method can be seen on picture 2 below:

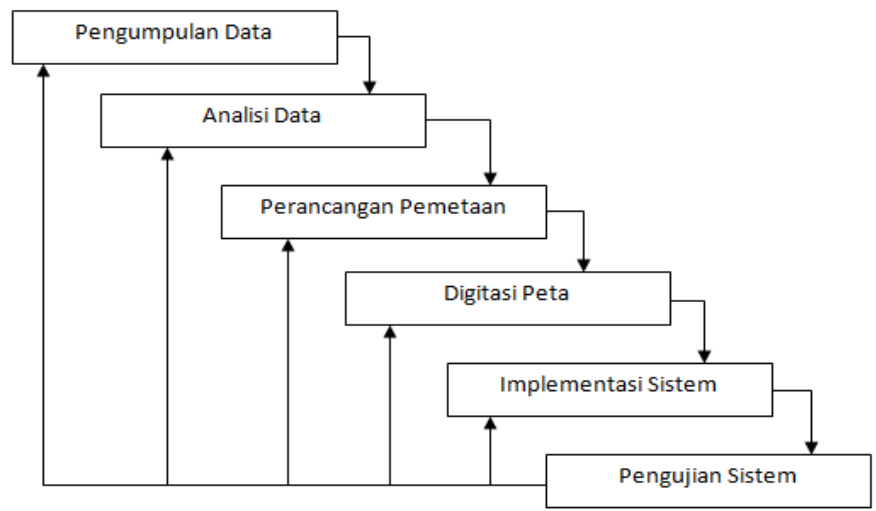

Figure 2. Metodologi Penelitian Menggunakan SDLC

\subsubsection{Collecting Data}

In this stage, detailed data collection of information from local cultural objects was conduct. The data obtained were divided into two groups, namely:

a. Spatial Data.

The spatial data in this research is a map of the city of Cirebon which is obtained from the official website

Cirebon City Government can be seen on picture 3 below:

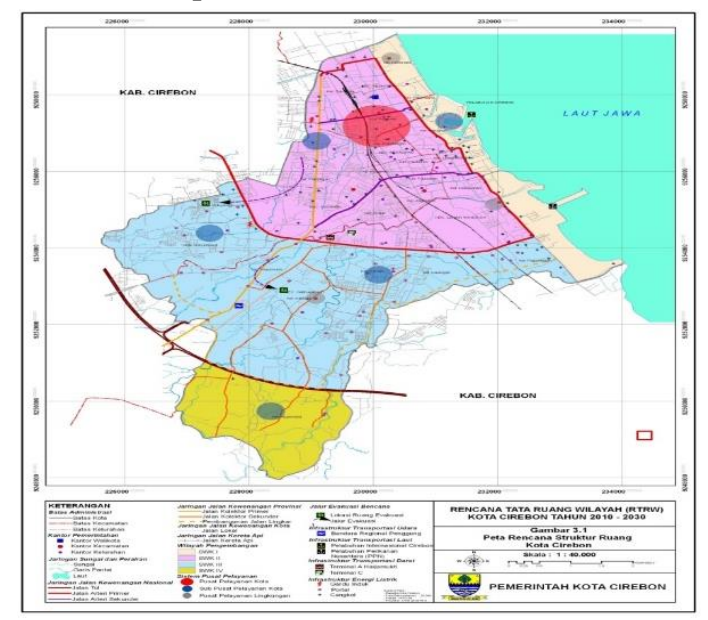


Figure 3. Data Spasial dari kota Cirebon

b. Non Spatial Data

Non-spatial data in this research is descriptive data of the research object taken samples and it showed in Table 1 below:

\begin{tabular}{cllll}
\hline \multirow{2}{*}{ No } & \multirow{2}{*}{ Object } & \multicolumn{2}{c}{ Titik Kordinat } & \multirow{2}{*}{ Klasifikasi } \\
\cline { 3 - 4 } & & Latitude & Longitude & \\
\hline 1 & Keraton Kasepuhan & -6.7263338 & 108.5710061 & Cagar Budaya \\
2 & Keraton kanoman & -6.7223931 & 108.567824 & Cagar Budaya \\
3 & Keraton Kacirebonan & -6.7247768 & 108.5655061 & Cagar Budaya \\
4 & Masjid Agung Sang Cipta Rasa & -6.725547 & 108.5678397 & Cagar Budaya \\
5 & Klenteng Dewi Welas Asih & -6.7179053 & 108.5681753 & Cagar Budaya \\
6 & Taman Sari Gua Sunyaragi & -6.7321441 & 108.5306578 & Cagar Budaya \\
7 & Sentra Batik Trusmi & -6.7034981 & 108.505336 & Kesenian \\
8 & Topeng Cirebon & -6.7372284 & 108.5435642 & Kesenian \\
9 & Empal Gentong H.Apud & -6.7298756 & 108.5229648 & Kuliner Khas \\
10 & Nasi Lengko H. Said & -6.716883 & 108.541872 & Kuliner Khas \\
11 & Nasi Jamblang Buk Nur & -6.7144204 & 108.5528076 & Kuliner Khas \\
12 & Tahu Gejrot Mas Iksan & -6.7312072 & 108.5539948 & Kuliner Khas \\
13 & Kerupuk Melarat & -6.7134637 & 108.5591023 & Kuliner Khas \\
14 & Sirup Buah Tjampolay & -6.7378958 & 108.5632525 & Kuliner Khas \\
15 & Terasi Cirebon Toko Daud & -6.7154286 & 108.558345 & Kuliner Khas \\
\hline
\end{tabular}

\subsubsection{Analyzing Data}

This stage is analyzes the previous data obtained and adjusts the needs in the mapping design, there are: coordinate points, descriptions and others.

\subsubsection{Designing the Mapping}

This stage was conducted the mapping design based on the data obtained. Mapping aims to provide convenience during the map digitizing process. In this research, mapping was carried out using Geojson. GeoJSON is a format for coding various geographic data structures based on the JSON (Javascript Object Notation) format. GeoJSON supports several geometry types such as Point, LineString, Polygon, and other multi-geometry types [12]. With GeoJSON, it can be easier in terms of digitizing maps. Mapping is done using spatial data and it can be seen on picture 4 below:

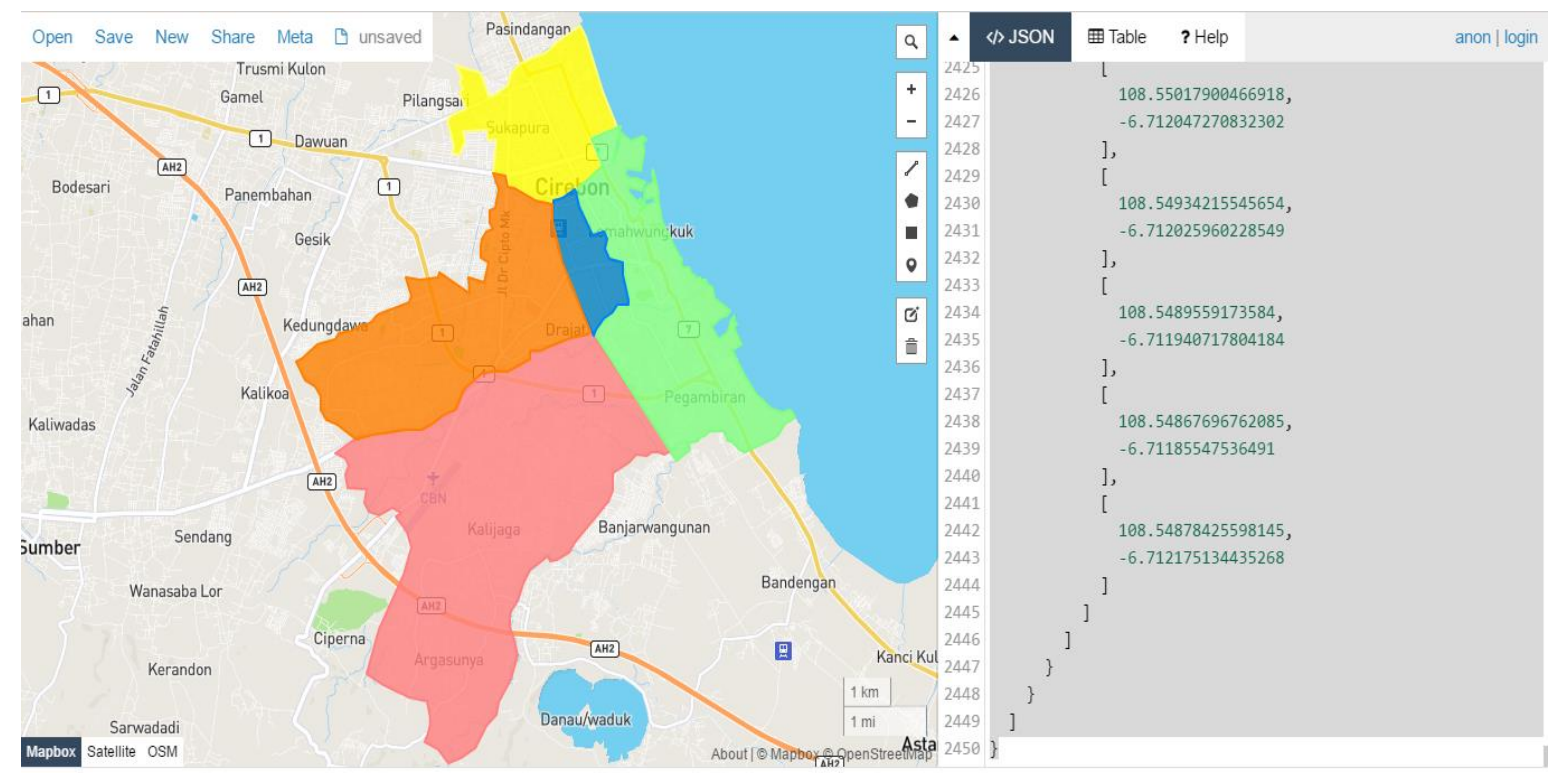




\section{Figure 4. Pemetaan data spasial dengan Geojson}

Furthermore, mapping for non-spatial data is a coordinate points can use the JS Leaflet to map coordinates. JS Leaflet is an Open Source Javascript Library which is useful for building an interactive map based on web or mobile [13]. To map coordinate points can be seen on picture 5 below:

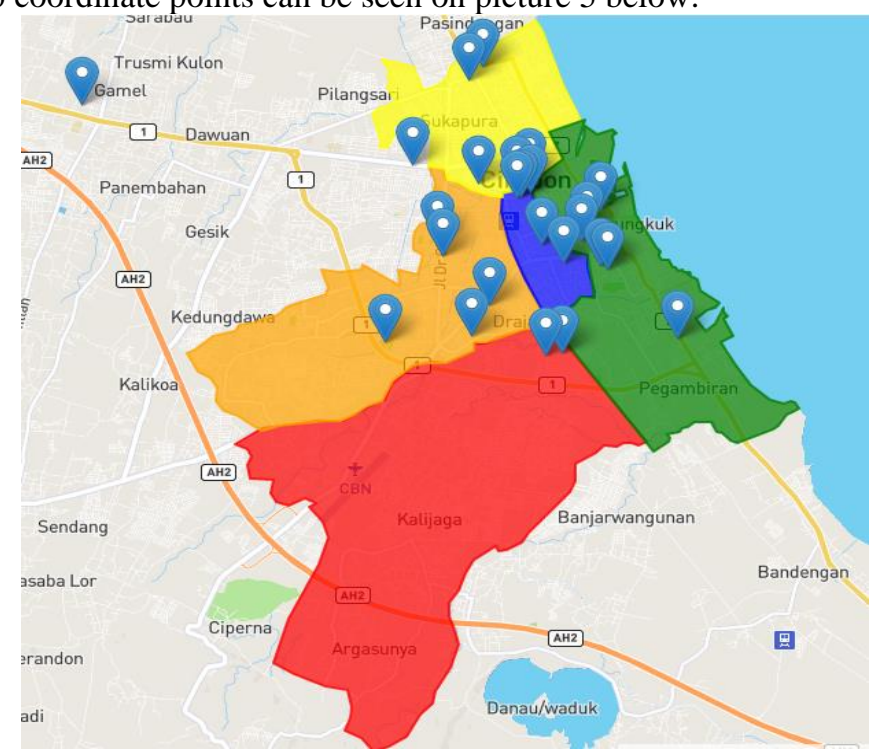

Figure 5. Pemetaan data non spasial dengan Leaflet JS

\subsubsection{Digitizing the Map}

This stage is digitizes the map based on the mapping has been made by using Geojson and JS Leaflet, it will automatically generate a digital map that can be implemented. The results of digitizing the map can be seen on picture 6 below:

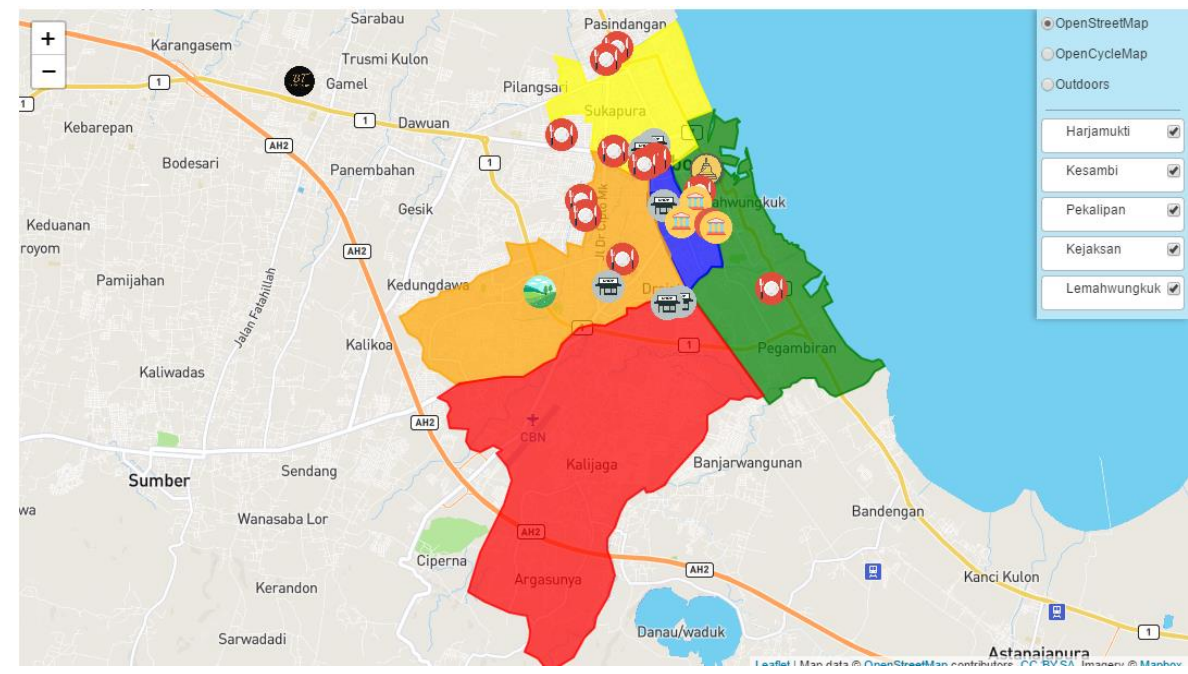

Figure 6. Digitasi Peta

2.2.5 Implementing the System

Before implementing the results of digitizing the map into the system, it is necessary to design a model of the system will be built. The design of the model in this research was made using the Unified Modeling Language (UML). The UML used consists of:

a. Use Case Diagram

The system to be built consists of 2, they are: Frontend and Backend. Use Case Diagrams are used to explain the user's relationship with the system. For the Frontend used by users with a Use Case Diagram it can be seen on picture 7 below: 


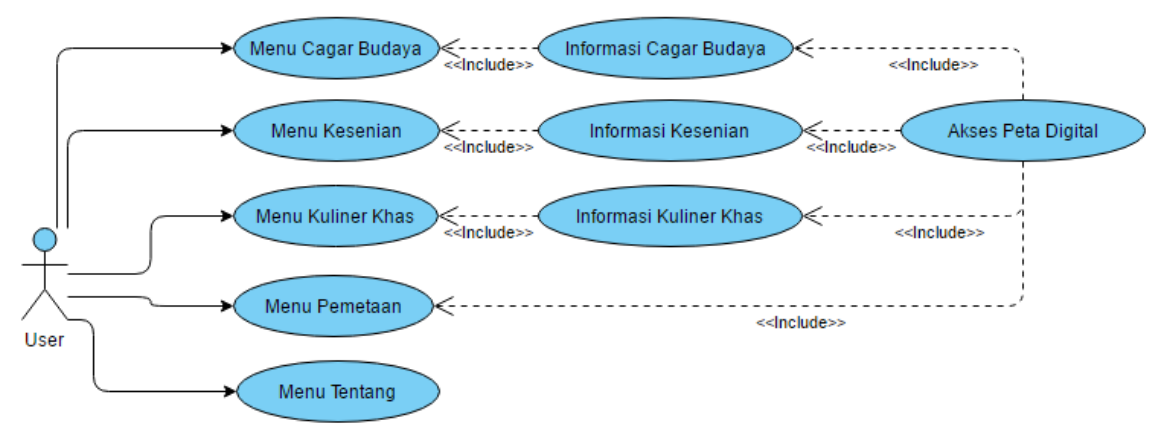

Figure 7. Use Case Diagram untuk Frontend

As for the Backend system used by admins with a Use Case Diagrams can be seen on picture 8 below:

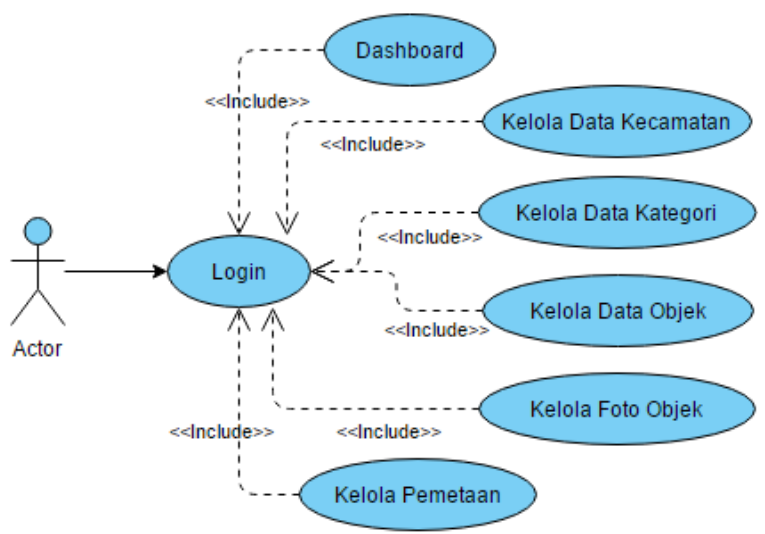

Figure 8. Use Case Diagram untuk Backend

b. Class Diagram

Class diagrams describe the relationships between the tables in the database that will be used as data containers in the system. The class diagram can be explained on picture 9 below:

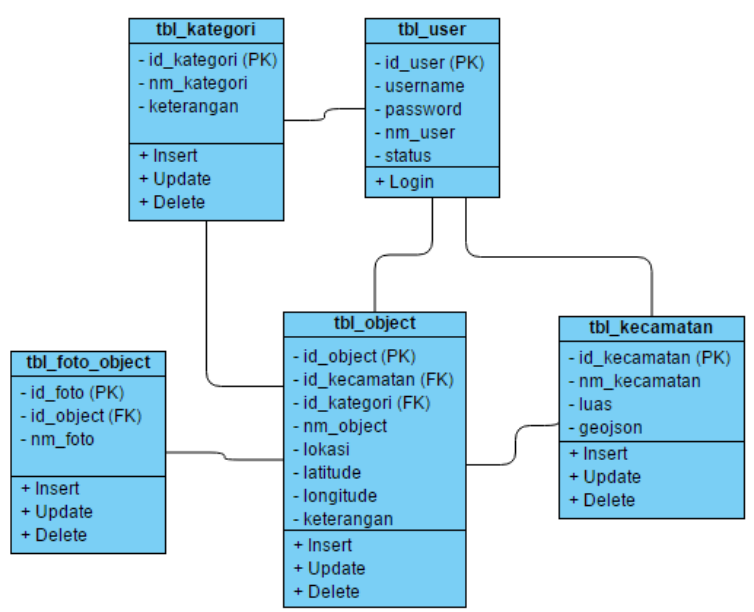

Figure 9. Class Diagram

Furthermore, with the design of this model, it can be built an Android-based GIS to make easy for users to find out the location and detailed information of leading local cultural objects wherever and whenever.

\subsubsection{Testing System}


Testing system aims to determine the weaknesses of the system has been built. By testing, it can be seen whether the system can run well or not and in this application whether it can help tourists find out information on leading local cultural objects.

\section{Result and Discussion}

From the research methodology was conducted, an Android-based GIS application is produced as follows: a. Main Page and Sub Menu of GIS

On the main page, there are menus can be used to access information on Cirebon local cultural objects that are in GIS. Then, from the menu on the main page, there is a sub menu to directs information on the object of research. The main page and sub menu in GIS can be seen on picture 10 below:

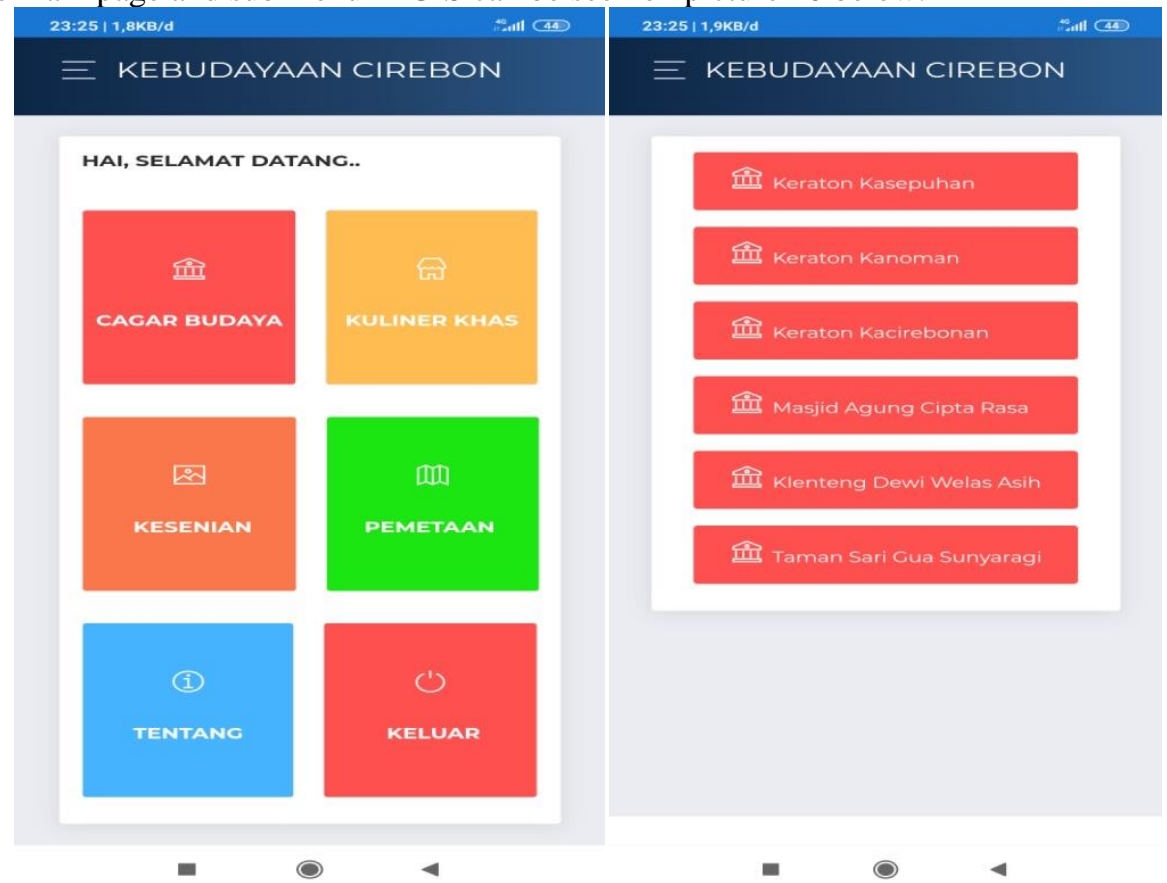

Figure 10. (a) Halaman Utama, (b) Sub Menu dari menu utama

b. Object Information Page and Mapping Menu

On the Object Information Page, information will be displayed on images and descriptions of the object. On the Mapping menu page, displays menus to the map of object location. The Object Information page and Mapping Menu in GIS can be seen on picture 11 below: 


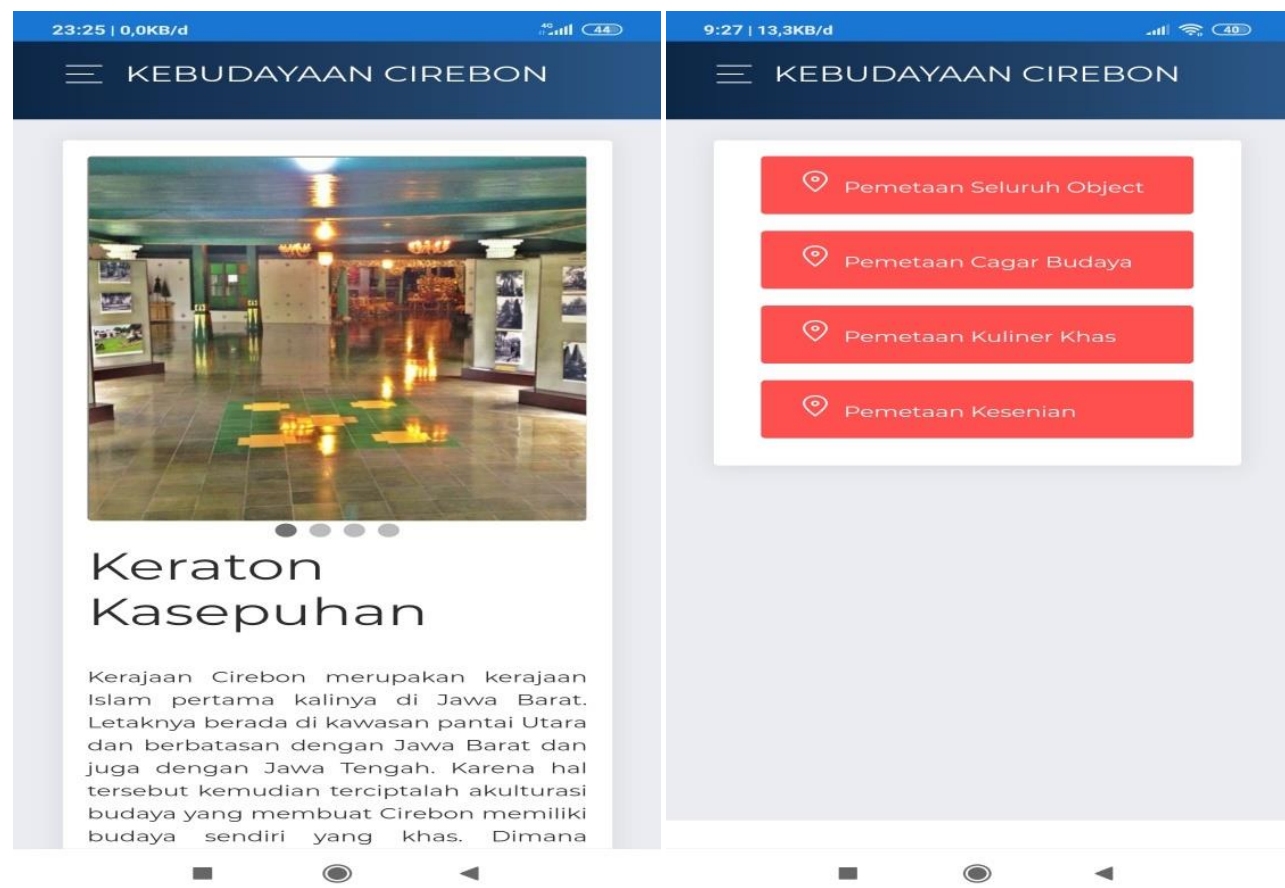

Figure 11. (a) Halaman Informasi Objek, (b) Menu Pemetaan

c. Mapping All Objects and Specific Objects

Mapping of all objects is the determinating of the location points of all local cultural objects of Cirebon.

Mapping specific objects is determining the location of objects based on their classification. Mapping of All Objects and Specific Objects in GIS can be seen on picture 12 below:

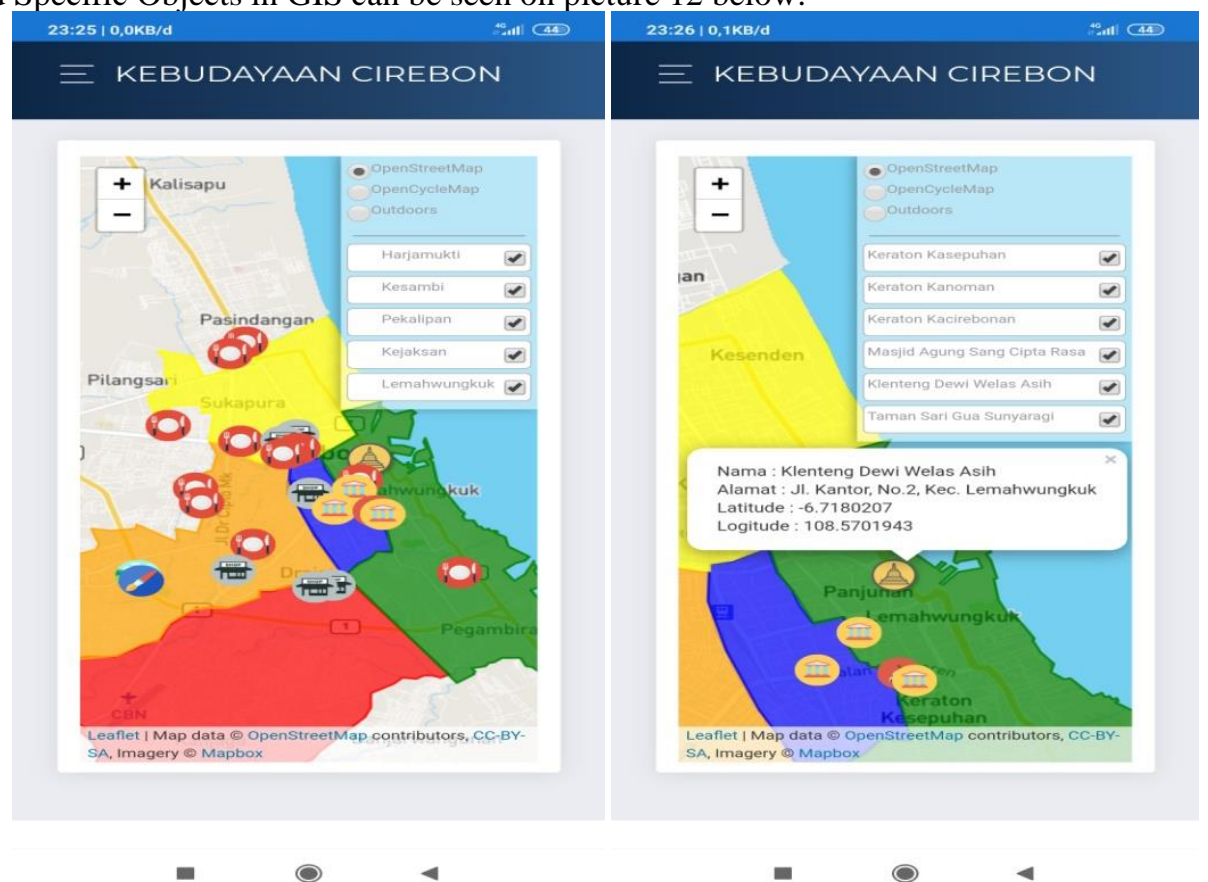

Figure 12. (a) Pemetaan Seluruh Objek, (b) Pemetaan Objek Tertentu

As a result of the system has been built, the mapping of Cirebon local culture has been digitizing the map can be implemented into an Android-based GIS, so it can be accessed via gadgets and smartphones.

\section{Conclusion}

Based on the research has been done, a map digitization of the local culture of Cirebon city has been produced, which consists of objects of Cultural Heritage, Art and Typical Culinary, which produced 15 
research objects. The results of this mapping, there are 2 research objects are outside Cirebon city, but are still part of the culture of Cirebon. Digitizing maps using Geojson and JS Leaflets makes easy to implement maps into an Android-based geographic information system. The Android-based Geographic Information System has been produced can make easier for users to find information about local cultural tourism in Cirebon city.

\section{References}

[1] Prayogi, R. dan Danail, E. (2016). "Pergeseran Nilai-Nilai Budaya Pada Suku Bonai Sebagai CIVIC CULUTURE Di Kecamatan Bonai Darussalam Kabupaten Rokan Hulu Provinsi Riau” HUMANIKA, Volume 23, Nomor 1, pp.61-79, ISSN: 1412-9418.

[2] Khoir, F., Ani, H.M. dan Hartanto, W. (2018). "Kontribusi Sektor Pariwisata Terhadap Pendapatan Asli Daerah Kabupaten Jember Tahun 2011-2017” Jurnal Pendidikan Ekonomi, Volume 12, Nomor 2, pp.199-206, ISSN: 1907-9990.

[3] Palabiran, M., Cahyadi, D. dan Arifin, Z. (2015). "Sistem Informasi Geografis Kuliner, Seni dan Budaya Kota Balikpapan Berbasis Android” Jurnal Informatika Mulawarman, Volume 10, Nomor 1, pp.54-57.

[4] Prapitasari, L.P.A., Sumiari, N.K. dan Jayanti, N.K.D.A. (2016). "Sistem Informasi Geografis Pasar Tradisional di Wilayah Denpasar menggunakan Framework YII" Jurnal Ilmiah SISFOTENIKA, Volume 06, Nomor 2, pp.205-216.

[5] Prasodjo, T. (2017). "Pengembangan Pariwisata Budaya Dalam Perspektif Pelayanan Publik" Jurnal Office, Volume 3, Nomor 1, pp.7-12.

[6] Andri, L. (2016). "Seni Pertunjukan Tradisional Di Persimpangan Zaman: Studi Kasus Kesenian MENAK KONCER Sumowono Semarang” HUMANIKA, Volume 23, Nomor 2, pp. 25-31.

[7] Alawi, M., Ramdani, F. dan Pramono, D. (2018). "Pengembangan Sistem Informasi Geografis Cagar Budaya Di Malang Raya Berbasi Webgis, 3D dan Gamifikasi" Jurnal Pengembangan Teknologi Informasi dan Ilmu Komputer, Volume 2, Nomor 4, pp. 1464-1474, ISSN: 2548-964X.

[8] Sendow, T.K. dan Longdong, J. (2015). "Studi Pemetaan Peta Kota (Studi Kasu Kota Manado)" Jurnal Ilmiah MEDIA ENGGINEERING, Volume 02, Nomor 01, pp. 35-46, ISSN: : 2087-9334.

[9] Rahardjo, D. dan Warkim, (2015). "Prototipe Sistem Informasi Geografis Fasilitas Kesehatan Di Kota Cirebon Berbasis Web” Jurnal Teknik Informatika dan Sistem Informasi, Volume 1, Nomor 3, pp. 210-220, ISSN: 2443-2229.

[10] Wibowo, K.M., Kanedi, I. dan Jumadi, J. (2015). "Sistem Informasi Geografis Menentukan Lokasi Pertambangan Batu Bara Di Provinsi Bengkulu Berbasis Web” Jurnal Media Infotama, Volume 11, Nomor 1, pp.51-60, ISSN: 1858-2680.

[11] Zulafwan, (2016). "Sistem Informasi Geografis Pemetaan Perkebunan Sawit Berbasis Web" Riau Journal Of Computer Science, Volume 2, Nomor 2, pp.7-16, ISSN: 2477-6890.

[12] Ibnu, W. Dan Jazman, M. (2017). "Rancang Bangun Sistem Informasi Geogafis Pemetaan Ruang Ujian Menggunakan Bootstrap dan Leaflet.js" SNTIKI 9, Pekan Baru 18-19 Mei 2017, pp.257-264.

[13] Evan, J.T., Silvia, R. dan Andreas, H. (2013). "Pemetaan Surabaya Heritage Dengan Geographic Information System" Media Neliti, Volume 1, Nomor 1, pp.1-4 